\title{
13 Transformation, fragmentation and decolonisation
}

\author{
The contested role of the media \\ in postcolonial South Africa
}

\author{
Ylva Rodny-Gumede
}

\section{Introduction}

Alongside global debates around the role of the news media amidst competition from social media and declining readership and faltering business models, debates in post-apartheid South Africa have foregrounded ideas of racial and gender equity in the newsroom as well as in the content of the news media. More recently, and emanating specifically from centres in the global South, these debates and concerns have shifted to focus on transformation that addresses colonial histories and legacies that shape the news media and the role that it should play in a changing political landscape.

Globally, the role of the news media is debated, and in an ever-evolving media industry it is heavily influenced by technological developments. With regard to the South African context, and with reference to transformation and decolonisation debates, it is important to note the contention that, amidst global shifts and technological changes, the news media and journalism has not changed much in terms of the role it assigns itself, and debates in and around the news media continue to be contested.

The most important public, as well as policy, debates in post-apartheid South Africa have concerned transformation in various sectors of society. Similarly, debates with regard to the news media have foregrounded ideas around transformation and issues have ranged from how to make the journalistic corps and news producers in general more equitable in terms of race and gender to the transformation of news content itself amidst criticism of racism and too narrow a focus on issues concerning only a small wealthy urban elite. As this range of priorities suggests, transformation in the media is a contested notion. And whereas equity in the workforce was high on the agenda in the first ten years of democracy, diversity in news content has emerged as higher on the priority list in the last 15 years, and this with a strong emphasis on access, in the first instance to mainstream media outlets and in later years, to new media platforms and social media.

More recently, debates and concerns have shifted to focus on transformation that runs deeper and that addresses colonial histories and legacies that shape the news media and the role that it should play in a changing 
political landscape characterised by renewed and amplified calls for a decolonisation of all sectors of society. With renewed calls for a speedier and deeper transformation and decolonisation of the media as presently enmeshed in, and expressed through, colonial legacies, it is clear that media transformation needs to be rethought in ways that talk less to the normative, idealist and long term, and instead to the real and experienced, in the present.

In this chapter, I revisit some of the debates around the role of the news media in South Africa. In doing so, I situate the South African news media in the postcolonial discourse and outline some of the contestations around social transformation, equity the political functions of the news media and journalism in contemporary society and in deepening democracy and democratic deliberation.

\section{Failures of social transformation}

Fundamental to understanding the decolonisation debate as it relates to the news media is an underlying failure of media transformation that springs from how social transformation as a whole tends to be a slow process in transitional societies and young democracies, let alone postcolonial societies. Studies of the news media in young democracies as well as transitional societies show that social transformation has often lagged behind political change and, as a result, the news media have also failed to transform. New institutions are formed on the remnants of the old and transformation can be lodged within a former authoritarian political system that is carried over and internalised by the new liberal democratic political dispensation (Downing 1996; O’Neil 1998; Sparks 2005, 2009; Sükösd 2000). This can be seen in the post-apartheid ANC-led governments' efforts to control the news media (Hadland 2007, 2012; Rozumilowicz 2002). The ways in which the ANC has tried to tighten its grip over the news media, including proposed new media legislation in South Africa, are indicative of this (Hadland 2007, 2012).

In addition, there are a range of demands put on the news media in postcolonial societies. Postcolonial societies stand apart from other transitional societies in the way in which the news media has been shaped by legacies of colonialism and, in the case of southern Africa, by apartheid and its aberrations. The legacies of colonialism and the continuous inequities it has created have made sure that state formation, politics and socio-economic development in the postcolony have remained premised on divisions of race (Rodny-Gumede 2020), and as Frassinelli (2018:4) states, 'race continues to be a marker of social difference, hierarchy and pain'. This, as Wasserman (2018:50) argues, also has implications for the news media on the continent and its audiences as reflected through 'the shared experience of a colonial subjection, struggles for independence and continued geopolitical and economic marginalization'. 
Added to this are the challenges posed by restructuring a liberation movement into a fully fledged democratic government and counter-tendencies of partisanship and co-option of the media. Postcolonial governments also face the challenge of developing a common sense of identity and sense of belonging and have often used the news media, particularly state broadcaster, for nation-building projects. In South Africa, as in many other postcolonial societies, there has for centuries existed a disjuncture between the state, on the one hand, and the diversity of ethnic, religious and language groups, on the other. The years after the first democratic elections ushered in an era of reconciliation and unity championed and represented by the late President Mandela. Under the banner of the "Rainbow nation", Mandela argued that boundaries between different population groups in South Africa should no longer have a bearing on state formation and social inclusion/exclusion in South Africa.

The notion of South Africa as a rainbow nation is, however, contested and seen by many as an artificial construct without grounding in reality (February and Jacobs 2010). And as much as Mandela has been lauded for being a proponent of racial unity, he has also been criticised for advocating for a superficial form of nation-building, concerned more with trying to dissipate white fears of a backlash against the state, and for over-emphasising a form of nation-building in which national insignia such as the new South African flag and the new multi-lingual national anthem took precedent over a deeper reconciliation and prevention of tribalism and cultural essentialism. In recent years, the ANC-led government has instead adopted a more nationalist rhetoric (Filatova 1997), and advocated for a more extensive and speedier process of racial transformation to address the inequities caused by widening wealth gaps post-apartheid (Marais 2011; Sparks 2003).

In South Africa, critics argue that the new democracy is being eroded by an all-powerful ANC (Duncan 2014), and, as in many postcolonial societies, the distinction between the state and the government has largely been eroded by former liberation movements who once in power have presided over one-party states with little or no opposition (Gumede 2012). Therefore, contestation over media development is linked to its coverage of the role of the state and political parties; as such, calls for reporting in the national interest are often conflated with the political party interest (Daniels 2012).

Looking beyond South Africa, there is a varied literature on the role of democracy in African countries: some African political leaders have alleged that there is authoritarianism implicit in African traditional values, and that the respect for liberty, independent thought and tolerance is allegedly only rooted in Western liberal culture (Tomaselli 2003). Some scholars have, however, rebutted this argument (Sen 1999; Tomaselli 2003). In the South African context though, Gumede $(2007,2012)$ argues that very few liberation movements put much effort into building relevant democratic institutions, so that the separation of powers, an independent judiciary and a system of checks and balances between branches of government are often just mere 
appendages. The failure to establish relevant democratic institutions and proper checks and balances has consequences for the structure of the media and the role the media can play in the new democracy. Horwitz (2001) therefore argues that the culture of secrecy and partisanship that often characterises liberation movements makes it difficult to support a non-partisan and non-adversarial press, even after the political struggle is over. Bennett (1998) argues that liberation movements generally arise from societies where there is little civic group structure or social capital and as a result, due to lack of civil and social organisation, many resistance movements fail to establish democratic governance structures. As a result of the absence of a legitimate civil society, the crucial phase of constructing democratic institutions is hindered by the lack of local social contexts and community forums in which to anchor and process political communication (Bennett 1998). South Africa however stands out in this regard where strong civil society organisations and coalitions, such as the Right to Know campaign and Save Public Broadcasting (SOS), have managed to keep the pressure up on government by opposing potentially restrictive legislation and have also lobbied for, and instigated transformation and diversification in the media (Sparks 2011).

This said, the new South African government has, since coming to power, adopted a largely market-friendly economic policy with the result that the media sector has been liberalised and de-regulated to a much higher extent than during the years of apartheid. This is a trend that many critics argue has led to increased commercialisation, "infotainment" and ownership concentration, at the expense of media diversity and pluralism and due to the increased sensitivity to commercial interests, it is argued that the South African media have not contributed to the democratic education of society to the extent that it could. There is thus tension between political control and market-driven changes and the media are caught in the contradiction between controls dictated by the new political establishment, on the one hand, and the market, on the other. And in the new South African democracy, elements of an old paternalistic, authoritarian system blend with more pluralist elements (Hadland 2012).

This said, the centrality of the news media to democratic processes, and in facilitating access to public discourse and civic engagement, is increasingly being questioned (Couldry 2009; Dahlgren and Sparks 1991; Rodny-Gumede 2017; Wasserman and Garman 2013). Research points to an increased fragmentation of the public sphere (Dahlgren 2005) as well as an increased audience disengagement within the traditional news media (World Association of Newspapers 2013), in particular with regard to younger audiences (Wasserman and Garman 2013). In many ways, scholars as well as scholarship have been divided into two camps of those who see the traditional news media as losing ground to new media outlets and platforms at the detriment of ensuring quality and trustworthiness of information disseminated in the public realm, vis-à-vis those who see the opportunities of the new media sphere for opening up opportunities for a diversity of views as 
well as facilitating access to a broader audience. The latter is important, and while much of the debate in the global North has focused on ideas around the changing media landscape and new challenges to journalism presented through new technology developments, new forms of audience interaction and participation and loss of editorial control, there are other issues that underline the development and fundamental ethos of the news media and journalism in transitional societies, and in particular postcolonial societies in the global South that talk to overcoming the many legacies of the past. One such issue, and the most important one, is how to make use of every means available to create a diverse and truly inclusive public sphere, as opposed to one still lodged in old conceptualisations of the audience as a small urban middle class.

All of this provides grounds for the continued contestations around the assumed role of the news media.

\section{The contested role of the news media}

In South Africa, as in many transitional societies, there is a prevailing political culture in which politicians are not accustomed to the open and scrutinising debate that is the characteristic of a democratic society, and hence they try to subordinate the media to their wishes. In South Africa, this can be seen in the ANC's attempts to control the public broadcaster, but also in their intolerance of critical voices in the print media. It also shows itself in the way that government has argued that the media should serve the national rather than the public interest. Black journalists and commentators, in particular, have come under pressure from government and have been accused of disloyalty for reporting on corruption and the failures of the ANC-led government.

Post-apartheid, many comparisons have been made between the present ANC-led government's treatment of the media and the old National Party's (NP) media policies (Brand 2008). Fourie and Oosthuizen (2001) state that the views of the ANC on South African and foreign media performance, and on media control and ownership have become increasingly like those of the NP government, accusing them of being unsupportive and unpatriotic and not contributing towards the development goals of government. Similarly, Johnston argues that the ANC's relationship with the press has been "distant and neurotically suspicious" at best, and "pathologically hostile" at worst (Johnston 2005). The uneasy relationship between the media and the government thus continues in the post-apartheid era. In very much the same manner as the NP criticised the white English-speaking press of being unpatriotic and spreading a false picture of South Africa abroad during the years of apartheid, the new government criticises the media for failing to take its responsibilities in a new South Africa. And much like the NP funded and controlled several media ventures, the ANC has advocated for a party-controlled media. Apart from increasing control over the SABC, 
the ANC was also been linked to the now defunct New Age, a newspaper launched in 2010 as a pro-ANC-government paper financed by business interests with links to former President Jacob Zuma (Benjamin 2010).

While government has criticised the news media for being untransformed, elitist and racist, and for looking at the world through "white" lenses, the news media itself argues that narrow policies of affirmative action based on race are fundamentally flawed and will have little or no impact on the standards or ethos of the news media and the role that the news media can play in a broader process of transformation and nation-building. Debates about national identity and the forging of national unity and how these debates play themselves out within the news media and in the role that it is assumed to perform are thus premised on tension between ideals of non-racialism, on the one hand, and African nationalists ideas and racialised politics that can serve divisionary agendas on the other (Marx 1998).

In later years, the mainstream Afrikaans- and English-speaking news media have often clashed with government over the role that media is assumed to play. The ANC-led government has often asked the news media to take a more developmental stance to journalism, urging journalists to be more supportive of the ruling party's policy agenda and achievements (Daniels 2012). At the same time, a large majority of South African journalists have emphasised their role as watchdogs of power, holding public officials accountable and exposing maladministration (Rodny-Gumede 2015b). This debate, as previously stated, has often been framed as whether the media should serve the "national interest", as mainly argued by government, or the "public interest", as generally maintained by the news media and journalists themselves (Wasserman and de Beer 2005).

In the main, and even if audiences have at times weighed in on debates, post-apartheid pressure against the mainstream press to transform has come predominantly from the ANC-led government. After the first democratic elections the press was perceived as being too white, and both former presidents, Mandela and Mbeki, were quite forthright in their critique of the media and the slow process of transformation (ANC 2007). Jacobs argues that it was not until leading ANC politicians, among these Mandela and Mbeki, started to "weigh-in" against the white face of the media that white media owners were convinced to undertake some kind of restructuring of ownership and control patterns (Jacobs 2007). However, Jacobs also argues that media owners probably initiated these changes 'for fear of government-imposed divestment or for fear of their business opportunities being obstructed in the new South Africa' (Jacobs 2007). Such pragmatic approaches to and motivations for transformation provide important context to the changing face of South Africa's news media.

Amidst the criticism levelled against the news media, the governing party has also at varying points in time suggested legislation to curb media freedom. Under the auspices of safeguarding pluralism in the media, the ANC has proposed a statutory Media Appeals Tribunal (MAT) (Berger 2010; 
Hadland 2007; Harber 2008; Wasserman 2010; Wasserman and de Beer 2006), including a new Protection of State Information Bill. The Bill known as the "Secrecy Bill" has the potential of making even the most inauspicious piece of government and state information classified and while passed in to legislation by Parliament already in 2013, former President Jacob Zuma as well as current President Cyril Ramaphosa has yet to sign it into law (deVos 2018). And while the ANC argues that media self-regulation has not been enough to ensure diversity and the protection of minority rights and interests in the media, critics argue that the suggested tribunal is less about the protection of rights than an attempt to muzzle the print media that so far have been difficult to co-opt, and that have kept up the pressure on government to deliver by scrutinising corruption in government and issues of non-performance (Daniels 2012).

What is lacking in this narrative, however, is the idea that, far from being co-opted by political powers, the South African news media have so far resisted attempts at coercion from government. Media houses, individual journalists, media advocacy groups and other civil society interest groups have lobbied and protested very successfully against threatening new media legislation. The suggested Media Appeals Tribunal (MAT), along with the proposed so-called "Secrecy Bill", has been discredited by activists, academics and the media fraternity, and is yet to be signed in to legislation.

And while the news media have in many ways resisted political influences and pressures, economic imperatives and the links between the new political power and the financial and economic elite have had implications for media ownership and control. This with consequences for how well the news media have been able to cover issues of public concern in relation to politics and power. Hence, when analysing the social, political and economic framework and how these have influenced the news media post-apartheid the picture that emerges is one of constant negotiation between structural constraints, imposed or not, real or perceived, and the agency and autonomy exercised by media houses, as well as individual journalists.

Even though the new 1996 South African Constitution guarantees the freedom of expression and the freedom of press, questions have been raised about new forms of censorship and ways of controlling the media post-apartheid South Africa. Lessons from comparative studies of media systems around the world have shown us that, more than anything else, the political environment shapes the organisation and structure of the media. And while media liberalisation and media freedom have been encouraged in the transition from a previously authoritarian political framework, the new leadership has found it hard to support an all too liberalised media and has employed various strategies to suppress them. The proposed new media legislation is indicative of this.

In later years, there have also been increased attacks on the news media from various public, as well as private individuals and the entities they represent. And instead of engaging in public debates around their grievances or 
taking cases to the Press Ombudsman, political parties and public officials are increasingly attacking journalists and editors through social media. In addition, journalists have been stalked and attacked outside their homes, and their properties have been destroyed (Rodny-Gumede 2019). A new threat against women journalists in particular has also emerged in the form of the cyber misogyny and attacks levelled at female journalist through social media (Rodny-Gumede 2019). ${ }^{1}$

In addition, key to understanding the renewed emphasis on decolonisation is understanding some of the failures in achieving equity in the organisation, workforce and content of the news media.

\section{Lack of equity in the news media}

After the first democratic elections in 1994, media transformation was high on the agenda, with a strong emphasis on transformation of the workforce. Since black people were excluded from the workforce for so long, a quick change of colour, in terms of both the workforce and the ownership of the media, became the main focus of attempts at transforming the news media post-apartheid. By creating equity in terms of race and gender, and to a lesser extent class, media content was thought to become more reflective of society at large. Affirmative action policies speak to a belief that social demographics of journalists do matter and if those who produce media content become more representative of society as a whole, diversity in media content will follow (Williams 2003: 105). As such, media policy debates have been heavily influenced by the broader affirmative action project that has informed transformation projects post-apartheid (Steenveld 2002). In the news media, affirmative action has contributed mainly to changes in ownership as well as newsroom staff where equity in terms of race and gender has been achieved (Lowe Morna 2018).

In particular, there have been changes at top management level in the news media. The proportion of white men in top management has gone down from $46 \%$ in 2006 to $14 \%$ in 2018 and for white women from $23 \%$ to $6 \%$ over the same period. However, the proportion of black men in top management in the media has more than doubled from $22 \%$ in 2006 to $50 \%$ in 2018. The proportion of black women in top management has gone up fivefold, from $6 \%$ in 2006 to $30 \%$ in 2018, but this is still 20 percentage points lower than for black men (Lowe Morna 2018: 37). Despite headways made, women still remain underrepresented in senior positions in the news media and at media company board level. And while, since 2009, there has been an increase in women's representation at senior and top management, this still falls short of the $50 \%$ mark. The proportion of women at board level has decreased from 38\% in 2009 to 19\% in 2018 (Lowe Morna 2018: 34).

However, research shows that the strong focus on racial equity in the newsroom has not been enough to create a news media that truly supports an inclusive participatory democracy and that gender equity in the workforce has 
not necessarily translated into a diversification of content (Rodny-Gumede 2015a, 2015b). Hence in later years, more focus has been put on the transformation and diversification of coverage and on reaching a broader audience and, in particular, on audiences previously excluded from the mainstream media (Rodny-Gumede 2015a, 2015b, 2015c). In addition, the need for journalists to be more cognisance of diverse audiences in terms of language, culture and socio-economic background has been raised (Rodny-Gumede 2015a). Research shows that journalists still feel circumscribed by race and gender (Rodny-Gumede 2015c). Interviews with South African journalists indicate that, on the one hand, there is a new awareness around race as well as gender developing among journalists and South African journalists are increasingly reflecting on their own background in relation to demographics such as race, class and gender and how this plays itself out in politics and social relations in South Africa (Rodny-Gumede 2015c). Media transformation debates have often highlighted that the broader public discourse shaped through the news media is still dominated by a narrow focus on the interest of a small white wealthy urban elite (Rodny-Gumede 2015a; Wasserman and DeBeer 2005; Wasserman and Garman 2013). This means that the voices of marginalised communities, largely those made up of women and children, seldom come through in media coverage (Rodny-Gumede 2015c).

Thus, higher equity in the workforce has not necessarily contributed to a broader transformation and diversification of media content and nor has actual editorial control improved equity in the newsroom. Research suggests that while more black people have taken up positions in the news media, giving them effectual operational control, this does not extend to allocative control in terms of having the power to hire and fire directors who fail to operate in the best interest of shareholders for example (Duncan 2011). And in terms of gender, equity has not been enough to make a broader impact on public discourses post-apartheid nor has it significantly contributed to widening access to the news media (Rodny-Gumede 2015a).

Of course, in later years, social media has gained importance and the rise of new media platforms and proliferation of social media has without a doubt been the most impactful transformation in the media sector as a whole in the last two decades. And political communication, as observed globally, has become more dependent on social media platforms and a new set of communicators as well as audience. The proliferation of social media platforms has fundamentally changed the way in which the news media interact with their audiences and ultimately the role that the news media play in a democracy - not to mention a nascent democracy and postcolonial society such as South Africa, where audiences are highly fragmented with large segments of the audience still cut off from the mainstream news media.

There are historical, cultural and political explanations as to how people understand and read the news media and how audiences are perceived and catered for. This extends to how the news media has historically served different segments of the audience and to a certain extent to how they continue 
to serve audiences in South Africa. Gone are the days of racist conceptualisations of the audience as reflected through "black editions" of newspapers and native or Bantustan news and newspapers overtly carrying an agenda of particular political ideologies and beliefs (Wasserman and de Beer 2005, 2006). However, the news media in South Africa is still fragmented and audiences are divided through socio-economic factors that dictate access and ideas around what is considered news. Language still fragments audiences and dictates the public interest of cultural groups in South Africa (Gassner 2007; Wasserman and de Beer 2005, 2006).

Access to the news media and public communications thus continues to be a problem even in the era of increased access to, as well as reliance on, social media.

\section{Conclusion}

This chapter has looked at how the South African news media have responded to the changes in the political and social environment postapartheid. Worldwide, the media are changing rapidly due to advances in technology and the media have also become much more global in scope and content. In South Africa, these changes are coupled with the political, social and cultural revolutions that have taken place in the country since the beginning of the 1990s. Yet, in spite of the tremendous changes that have taken place in the media since the end of apartheid, much still needs to be done in order for the news media to truly contribute to the strengthening and deepening of the nascent democracy.

The political environment has defined both the structures and the organisation of the news media, as well as the functions that journalists have been expected to perform. It shaped the role and conduct of the news media during apartheid, and has continued to do so after the dismantling of apartheid. The complex political environment has created a political culture that has defined policy formulation in South Africa, and has set the parameters for the role and conduct of the media and, ultimately, the content of that media. And, even though the end of apartheid has ushered in an era of new openness and willingness to transform the media, it has not automatically prevented government from trying to impose tighter state control. Nor has media independence brought with it the neutrality and non-partisanship many had hoped for. Old ways of conducting journalism and relating to the audience do not change that easily.

As both an agent for and site of transformation, the media were targeted in post-apartheid efforts to transform society at large. Foremost in these efforts was the formulation of affirmative action policies to employ more black and women journalists so as to rectify past discrimination. On the whole, these policies have been successful. However, there are still hurdles to be addressed. Race still informs much of the debates around the news media and there is still some way to go in order to increase women's participation, in particular, in shaping news agendas and in the extension broader public discourses. 
Racial transformation and policies of affirmative action are also highly contested. And while race remains an important variable to be factored into the discussion around media transformation, there is a need to move away from number games to more constructive debates around how to foster a new ethos for journalism and news coverage in post-apartheid South Africa.

It is clear that the decolonisation debate is premised on media transformation that remains uneven and a lack of consensus on what it should entail. Many unresolved issues remain in the media-politics nexus that keep influencing the structures, organisation and content of the news media as well as the role that the news media play in the postcolonial society. Many of the trends visible in the post-apartheid news media are not unique to South Africa. Similar trends have been observed in other transitional as well as postcolonial societies that, like South Africa, have undergone transitions from authoritarian regimes to capitalist liberal democracies. A cursory look at these transitions reveals that while there has been considerable political change, social transformation has often lagged behind and, as a result, the news media have also failed to transform.

While headways have been made in securing both racial and gender equity in the newsroom, issues around equity in news content and the role that the media can and should play in the new democratic society remain contested and critics argue that the broader public sphere remains the same as during the years of apartheid, reflecting old inequalities of access and power, and as such reflects the narrow political and economic transition that continues to unfold in South Africa (Jacobs 2007). This, independently of audiences accessing the traditional news media or newer digital and social media platforms.

And while much of the debate in the global North has focused on how to reinvent the news media to secure its future in the light of challenges posed by new technology influencing information dissemination and audience engagement, the news media in many postcolonial societies in the global South, South Africa included, will do better to re-affirm the role of the news media in democratic processes and democratic institution building and secure universal access.

\section{Note}

1 According to a 2018 world-wide study of female journalists by the International Women's Media Foundation more than half of the women journalists surveyed have suffered work-related abuse, threats or physical attacks (IWMF, 2018). Most worrying are the rising attacks on journalists that have emerged through social media, where female journalists are disproportionally targeted, in comparison to their male counterparts.

\section{References}

African National Congress (ANC). 2007. "Transformation of the media”, ANC Policy Discussion Document, March, 2007. 
Benjamin, C. 2010. Gupta group to fund 'ANC-sympathetic' newspaper. Available from: www.businessday.co.za/articles/Content.aspx?id=113830 (Accessed 15 January 2020).

Bennett, L. W. 1998. The media and democratic development. In P. O’Neil (Ed.), Communicating democracy: The media and political transitions (pp. 195-207). London: Lynne Rienner Publishers Inc.

Berger, G. 2010. Drop the media tribunal if you want a debate about the press. Available from: www.thoughtleader.co.za/guyberger/2010/08/16/drop-the-mediatribunal-if-you-want-debate-about-the-press (Accessed 12 January 2020).

Brand, R. 2008. The price of freedom: South Africa's media in 2008. Rhodes Journalism Review 28: 31.

Couldry, N. 2009. Does 'the media' have a future? European Journal of Communication 24(4): 437-449.

Dahlgren, P. 2005. The internet, public spheres, and political communication: Dispersion and deliberation. Political Communication 22: 147-162.

Dahlgren, P. \& Sparks, C. (Eds). 1991. Communication and citizenship - Journalism and the public sphere. London: Routledge.

Daniels, G. 2012. Fight for democracy: The ANC and the media in South Africa. Johannesburg: Wits University Press.

deVos, P. 2018. Why the failure of Presidents Zuma and Ramaphosa to deal with the Secrecy Bill is constitutionally delinquent. Available from: https://www. dailymaverick.co.za/opinionista/2018-07-19-why-the-failure-of-presidents-zumaand-ramaphosa-to-deal-with-the-secrecy-bill-is-constitutionally-delinquent/ (Accessed 15 January 2020).

Downing, J. 1996. Internationalizing media theory. London: Sage.

Duncan, J. 2014. The rise of the securocrats: The case of South Africa. Johannesburg: Jacana.

Duncan, J. 2011. South Africa: The print media dilemma. Available from: http:// allafrica.com/stories/printable/201103030841.html (Accessed on 15 January 2020).

February, J. \& Jacobs, S. 2010. If a country lives by its myths, then the myth of post-apartheid South Africa must be that it had become 'the rainbow nation'. Mail \& Guardian, 23 March. Available at: http://mg.co.za/article/2001-03-23madibas-magic-is-slowly-dissipating (accessed 15 January 2020).

Filatova, I. 1997. The rainbow against the African sky or African hegemony in a multi-cultural context? Transformation 34: 47-56.

Fourie, P. J. \& Oosthuizen, L. M. 2001. Media imperialism: The new world information and communication order. In P. J. Fourie (Ed.), Media Studies: Institutions, Theories and Issues (vol. 1, pp. 415-446). Cape Town, South Africa: Juta.

Frassinelli, P. P. 2018. Decolonisation: What it is and what research has to do with it. In K. G. Tomaselli (Ed.), Making Sense of Research (pp. 3-9). Pretoria: van Schaik Publishers.

Gassner, P. 2007. The end of the audience. How the nature of audiences changed. Global Media Journal-African Edition 1(1): 120-129.

Gumede, W. 2012. Restless nation: Making sense of troubled times. Cape Town, South Africa: Tafelberg.

Gumede, W. 2007. Democratic deficit: Africa's lost years. Speech delivered at The Basker Vashee Memorial Lecture, Transnational Institute, De Balie, Amsterdam, 15 June. 
Hadland, A. 2012. Africanizing three models of media and politics: The South African experience Adrian Hadland. In D. Hallin \& P. Mancini (Eds.), Comparing media systems beyond the Western world (pp. 96-118). London: Cambridge University Press.

Hadland, A. 2007. The South African print media 1994-2004: An application and critique of comparative media systems theory. $\mathrm{PhD}$ thesis University of Cape town, South Africa.

Harber, A. 2008. 2007 overview. Available from: http://www.theharbinger.co.za/ wordpress/2008/01/05/2007-overview (Accessed on 15 January 2020).

Horwitz, R. B. 2001. Communication and democratic reform in South Africa (p. 283). Cambridge: Cambridge University Press.

IWMF (International Women's Media Foundation). 2018. Violence and harassment against women in the news media: A global picture. Available from: (https:// www.iwmf.org/wp-content/uploads/2018/06/Violence-and-Harassment-againstWomen-in-the-News-Media.pdf). (Accessed 12 January 2020)

Jacobs, S. 2007. The media picture: Mapping the contemporary media scene in South Africa. In G. Gunnarsen, P. MacManus, M. Nielsen, \& H. E. Stolten (Eds.), At the end of the rainbow? Social identity and welfare state in the new South Africa (pp. 153-163). Copenhagen, Denmark: Africa Contact.

Johnston, A. 2005. The African National Congress, the print media and the development of mediated politics in South Africa. Critical Arts 19(1\&2): 12-35.

Lowe Morna, C. 2018. Glass ceiling: Women in South African news media. South Africa: GenderLinks.

Marais, H. 2011. South Africa pushed to the limit: The political economy of change. Cape Town: UCT Press.

Marx, A. W. 1998. Making race and nation: A comparison of South Africa, the United States, and Brazil. Cambridge: Cambridge University Press.

O’Neil, P. 1998. Democratization and mass communication. In Communicating democracy: the media and political transitions. Edited by O'Neil, P. London: Lynne Rienner Publishers Inc, pp.1-20.

Rodny-Gumede, Y. 2020. Expanding comparative media systems analysis from transitional to postcolonial societies, International Communication Gazette. Published online 23 January 2020.

Rodny-Gumede, Y. 2019. Cyberattacks on female journalists threaten everyone. Available from: https://mg.co.za/article/2019-03-06-cyberattacks-on-female-journaliststhreaten-everyone. Mail\&Guardian, 6 March. (Accessed 17 March 2020).

Rodny-Gumede, Y. 2017. Questioning the media-democracy relationship in view of the post-colony. Communication 43(2): 10-22.

Rodny-Gumede, Y. 2015a. An assessment of the public interest and ideas of the public in South Africa and the adoption of 'Ubuntu journalism'. Journal of Media Ethics 30(2): 109-124.

Rodny-Gumede, Y. 2015b. South African journalists' conceptualisation of professionalism and deviations form normative liberal values. Communicare 33(2): $54-69$.

Rodny-Gumede, Y. 2015c. Gender and public discourse formation in South Africa: Male and female journalists' influence on news agendas. Communication: South African Journal for Communication Theory and Research 41(2): 206-219. 
Rozumilowicz, B. 2002. Democratic change: A theoretical perspective. In M. E. Price \& B. Rozumilowicz \& S. Verhulst, Media reform: Democratizing the media, democratizing the state (pp. 9-26). London: Routledge.

Sen, A. 1999. Development as freedom. Oxford: Oxford University Press.

Sparks, A. 2003. Beyond the Miracle, Inside the New South Africa. Cape Town, South Africa: Jonathan Ball Publishers.

Sparks, C. 2011. South African media in a comparative perspective. Ecquid Novi: African Journalism Studies 32(2): 5-19.

Sparks, C. 2009. South African media in transition. Journal of African Media Studies 1(2): 195-220.

Sparks, C. 2005. Civil society as contested concept: Media and political transformation in Eastern Europe. In R. A. Hackett \& Y. Zhao (Eds.), Democratizing global media: One world, many struggles (pp. 37-56). Oxford: Rowman \& Littlefield Publishers Inc.

Steenveld, L. 2002. The South African national editors' forum and the independent newspapers' chair of media transformation (pp. 65-68). Grahamstown: Rhodes University.

Sükösd, M. 2000. Democratic transformation and the mass media in Hungary: From Stalinism to democratic consolidation. In R. Gunther \& A. Mughan (Eds.), Democracy and the media: A comparative perspective (pp. 122-164). Cambridge: Cambridge University Press.

Tomaselli, K. G. 2003. Our culture" vs "foreign culture", an essay on ontological and professional issues in African journalism. Gazette: International Journal for Communication Studies 65(6), pp. 427-441.

Wasserman, H. 2018. Media, geopolitics, and power: A view from the Global South. Cape Town: UCT Press.

Wasserman, H. 2010. Tabloid journalism in South Africa. Bloomington: Indiana University Press.

Wasserman, H. \& de Beer, A. S. 2006. Conflicts of interest? Debating the media's role in post-apartheid South Africa. In K. Voltmer (Ed.), Mass media and political communication in new democracies (pp. 59-75). London: Routledge.

Wasserman, H. \& De Beer, A. S. 2005. Which public? Whose interest? The South African media and its role during the first ten years of democracy. Critical Arts 19(1-2): 36-51.

Wasserman, H. \& Garman, A. 2013. The meanings of citizenship: Media use and democracy in South Africa. Social Dynamics: A Journal of African Studies 40(2): 392-407.

Williams, K. 2003. Understanding Media Theory. London: Arnold.

World Association of Newspapers and News publishers (WAN). 2013. World Press Trends: Print and Digital Together Increasing Newspaper Audiences. Available from http://www.wan-ifra.org/press-releases/2014/06/09/world-presstrends-print-and-digital-together-increasing-newspaper-audience (Accessed 2 March 2020). 